\title{
Medicinal Uses of Juniper Tree Cones
}

\author{
Loutfy I El-Juhany* \\ Prince Sultan Institute for Environmental, Water and Desert Research, King Saud University, Saudi Arabia
}

*Corresponding author: Loutfy I El-Juhany, Prince Sultan Institute for Environmental, Water and Desert Research, King Saud University, Riyadh, Saudi Arabia.

\section{Opinion}

The juniper plant is classified within the Plantae kingdom as it follows the Coniferophyte division, Pinopsida Class, Pinales order, Cupressaceae family, and Juniperus genus [1]. The genus Juniperus includes 60 species, all of which are found in the northern hemisphere, with only J. Procera in the southern hemisphere [2]. A number of juniper species are cultivated as ornamentals and are useful for their timber. Moreover, many parts of the juniper tree are used in the treatment of many diseases that afflict humans, and some of them have been known since ancient times. The cone of the juniper is the part that is referred to as the berry; it may be called fruits figuratively. The importance of juniper tree as a medicinal plant is due to the chemical composition of its cones. Research has shown that juniper berries contain at least 87 chemical compounds and are extremely high in flavonoid and polyphenols which are antioxidants [3]. The oldest record of the medicinal use of juniper fruits goes back to an ancient Egyptian papyrus dating back to 1500 BC, which contains a prescription for treating a tapeworm infection using juniper fruits [4]. The ancient Egyptians used juniper to mummify the dead bodies [5]. The Romans also used the fruits of juniper to purify the stomach from diseases, while the famous herbalist Culpeper from the Middle Ages recommended treating a wide range of ailments using juniper, including the treatment of flatulence (which Juniper oil is still used today). Juniper fruits have been used as medicine by many civilizations, and in ancient Egypt physicians used volatile juniper seed oil as a laxative since about 1550 BC [6]. Juniper cones have been found in ancient Egyptian tombs in multiple locations. The fruits of Juniperus excelsa and Juniperus oxycedrus were found in the tomb of Tutankhamen (1341-1323 BC) [7]. The Greeks used juniper fruits as medicine long before their use in foods was mentioned [8]. They also used juniper fruits on many of their Olympic Games occasions due to their belief that juniper fruits increased the physical endurance of athletes [9]. In the Americas, Zuni Indians used juniper fruits to aid in the birth process, while other Indians used juniper fruits and leaves to treat infections, arthritis, and wounds [10]. Western tribes in America used a mixture of the fruit of the common Juniperus communist with the bark of the roots of Berberis vulgaris to treat diabetes. Clinical studies have proven the effectiveness of this mixture in treating insulin-dependent diabetes. It has been shown that compounds in these two plants, when combined and swallowed, stimulate insulin production in fat cells in the body, as well as stabilize blood sugar levels. Indians also used juniper fruits as a contraceptive [11]. Juniper is used as a diuretic, antiseptic, and antimicrobial, as it has anti-inflammatory, anti-rheumatic, and stomachache properties, which are attributed to the volatile oils found in the cones [6]. This oil is a mixture of terpenes, flavonoids glycosides, sugar, tar, and resin, with terpenes- 4 and terpinen-4-ol, a diuretic compound that stimulates the kidneys and the flavonoid am into flavones have antiviral properties. It is believed that resins and tar can be used in the treatment of skin diseases such as psoriasis, and there is deoxypodophyllotoxins that can help inhibit the herpes simplex virus [6]. Among modern uses of juniper are also treatment of urinary tract infections and bladder because it is a powerful diuretic, and is also used to relieve chronic arthritis, gout, fluid retention, kidney disease, menstrual disorders, heartburn, indigestion, rheumatism, and other diseases [6]. The chemicals present in juniper fruits stimulate the contraction of the uterine muscles and thus can be helpful in facilitating the labor process. The same properties 
of these substances have also been used to abort an unwanted pregnancy [4]. Juniper was used by British herbalists to promote menstruation in women, and by the beginning of the 19th century American herbalists were using it as a treatment for congestive heart failure, urinary tract infections, and gonorrhea [6]. Juniper fruits have been used as a traditional treatment for cancer, arthritis, rheumatism, bronchitis, tuberculosis, and gout. Doctors often chew juniper cones when treating patients so that they would not be infected [6]. In the seventeenth century, the herbalist Nicholas Culpeper recommended the use of mature juniper cones to treat conditions such as asthma, and sciatica, as well as to accelerate labor [11]. Juniper cone oil is known to be an antiseptic, analgesic, and sedative, and it has also been known to be useful in treating tuberculosis, jaundice, eczema, and others [12-17]. In general, various materials are extracted from juniper trees that are useful in treating many diseases and health problems that afflict humans, and they are used in the habitats in which these trees are spread, and among those diseases are diarrhea, abdominal pain, tumors and respiratory tract injuries such as coughing and indigestion, as well as bark ash is used in treating some skin diseases. It is also used to relieve head and tooth pain, coughing, and to treat some skin diseases such as eczema, and it prevents hair loss [18]. Some juniper tree products are used as odor repellant incense in hospital patient rooms and clinics.

\section{Acknowledgement}

None.

\section{Conflict of Interest}

Author declare no conflict of interest.

\section{References}

1. World History Web (2004) Cupressaceae.

2. Adams RP, Demeke T (1993) Systematic relationships in Juniperus based on random amplified polymorphic DNAs (RAPDs). Taxon 42: 553-572.

3. Schley T (2018) Five Health Benefits of Juniper Essential Oil and How to Use it.
4. Kendall P (2015) Trees for life. Discover the forest, Mythology \& folklore, Juniper.

5. Waletrs LR (2004) The Herbal Encyclopedia: A Practical Guide to the Many Uses of Herbs. Universe Inc, New York, USA.

6. Wurges J (2005) Juniper. In: Longe JL The Gale Encyclopedia of Alternative Medicine, Farmington Hills, Mich: Thomson/Gale.

7. Manniche L (1999) Sacred Luxuries: Fragrance, Aromatherapy, and Cosmetics in Ancient Egypt. Cornell University Press, USA.

8. Dalby A (2002) Dangerous Tastes: The Story of Spices. University of California Press, USA.

9. Lorman J (1997) Greek Life. Gregory House: New York, pp. 76-77.

10. Tilford GL (1997) Edible and Medicinal Plants of the West. Missoula, Mont: Mountain Press Pub, USA.

11. Culpeper N (1990) Culpeper's Complete Herbal \& English Physician, Enlarged. Glenwood, Ill: Myerbooks.

12. Adams RP (1999) Investigation of Juniperus species of the United States for new sources of Cedar wood oil. Economic Botany 41: 48-54.

13. Ucar G, Balaban M (2002) The composition of volatile extractives from the wood of Juniperus excela, Juniperus foetidissima and Juniperus oxycedrus. Holz als Roh-und werkstoff 60: 356-362.

14. Marina D, Sokovic RM, Grubisic D (2004) Chemical composition and antifungal activity of the essential oil from Juniperus excelsa berries. Pharmaceutical Biology 42: 328-331.

15. Unlu M, Vardar-Unlu G, Vural N, Donmez E, Cakmak O (2008) Composition and antimicrobial activity of Juniperus excelsa essential oil. Chemistry of Natural Compounds 44: 100-101.

16. Derwich E, Benziane Z, Taouil R, Senhaji O, Touzani M (2010) A Comparative study of the chemical composition of the leaves volatile oil of Juniperus phoenicea and Juniperus oxycedrus Middle East. Journal of scientific Research 5(5): 416-424.

17. Orav A, Kailas T, Müürisepp M (2010) Chemical investigation of the essential oil from berries and needles of common juniper (Juniperus communis L) growing wild in Estonia. Natural Product Research 24: 1789-1799.

18. Al-Dawabi I (2016) Juniper. Muhammadiyah Association of Scholars in the Kingdom of Morocco, Association Charter, 226A. 